\title{
KONSEP DAN AKTUALISASI KOMPETENSI PEDAGOGIS GURU
}

\author{
Oleh: Sutarmanto ${ }^{1}$.
}

\begin{abstract}
Abstrak
Kompetensi pedagogis merupakan suatu perangkat kemampuan yang harus dimiliki guru berkaitan dengan proses pembelajaran dan pemahaman peserta didk. Secara komprehensif kompetensi pedagogis ini meliputi; pemahaman peserta didik, merancang pembelajaran, termasuk memahami landasan-landasan pendidikan untuk kepentingan pembelajaran, melaksanakan pembelajaran, merancang dan melaksanakan evaluasi pembelajaran, serta mengembangkan peserta didik untuk mengaktualisasikan berbagai potensi yang dimilikinya. Komponen-komponen komptensi ini bukan merupakan bagian terpisah, akan tetapi merupakan satu kesatuan integral bagi pembentukan guru profesional.
\end{abstract}

Kata-kata Kunci: Kompetensi Pedagogis, Profesionalisme Guru

\section{A. Pendahuluan}

Lembaga pendidikan dihadapkan pada tuntutan yang semakin berat, utamanya dalam rangka mempersiapkan peserta didik untuk mampu menghadapi berbagai dinamika perubahan yang berkembang demikian cepatnya. Perubahan-perubahan yang terjadi menyentuh hampir seluruh dimensi kehidupan individu dan masyarakat, termasuk perubahan cara pandang, cita-cita, harapan akan masa depan dan pergeseran nilai. Hal ini terjadi terutama sekali sebagai dampak dari kemajuan teknologi, khususnya teknologi komunikasi yang demikian cepat merambah kesemua lini kehidupan sosial masyarakat. Perubahan-perubahan tersebut berimplikasi pada tuntutan pemberian layanan yang lebih profesional agar individu mampu merespon brbagai dinamika persoalan yang dihadapi.

Para pendidik yang memahami bidang tugasnya secara menyeluruh serta tanggap terhadap berbagai fenomena perubahanperubahan yang terjadi, baik berkenaan dengan peserta didik maupun perubahan-perubahan yang terjadi pada lingkungannya merupakan bagian kemampuan professional yang harus dapat dimiliki oleh setiap guru.

${ }^{1}$ Sutarmanto adalah dosen Jurusan Ilmu Pendidikan FKIP-UNTAN Pontianak 
Dengan kata lain guru yang perfesional adalah guru yang memiliki kemampuan dan keterampilan yang memadai berkaitan dengan tugas profesinya dan selalu berupaya secara terus menerus meningkatkan kemampuan serta keterampilan dirinya guna mendukung kelancaran tugas-tugas yang ia emban. Parkey, (1998: 380), menegaskan bahwa tenaga profesional sebagai seorang yang memiliki landasan teori ilmu pengetahuan yang bersifat khusus, ditambah dengan kemampuan di dalam menguasai berbagai metode dan teknik yang diterapkan untuk membantu pekerjaannya sehari-hari, yang ia terikat ke dalam satu kesatuan yang memegang teguh solidaritas kelompoknya, di mana semuanya itu berakar dari adanya kebiasaan yang menjunjung tinggi latar belakang pendidikan dan kesetiaan terhadap kode etik dan metode-metode tertentu.

Dalam Undang-undang Nomor 14 tahun 2005 tentang Guru dan Dosen, disebutkan bahwa profesi guru dan dosen berfungsi untuk mengembangkan kemampuan, membentuk watak dan kecerdasan peserta didik dan mengembangkan ilmu pengetahuan, teknologi dan seni (IPTEKS). Untuk dapat mewujudkan fungsi tersebut maka setiap guru dituntut memiliki perangkat kemampuan yang memadai sehingga mampu menjalankan seluruh komponen tugasnya sesuai dengan arah, tujuan serta standar yang ditetapkan. Perangkat kemampuan yang diharapkan untuk dimiliki guru tersebut dalam Undang-undang di atas disebut "kompetensi". "Kompetensi adalah seperangkat pengetahuan, keterampilan dan perilaku yang harus dimiliki, dihayati dan dikuasai oleh guru dan dosen dalam melaksanakan tugas profesionalnya" (Pasal 1 Undang-undang Guru dan Dosen)

Dalam rangka mendukung profesionalisme guru sebagaimana diharapkan, maka setiap guru memiliki sekuranganya empat kompetensi dasar, yaitu kompetensi pedagogis, kompetensi kepribadian, kompetensi sosial dan kompetensi profesional. Meskipun ada pemilihan keempat kompetensi tersebut, namun dalam implementasinya merupakan satu kesatuan yang saling terkait. Oleh sebab itu pemahaman secara menyeluruh terhadap muatan dari kompetensi-kompetensi ini menjadi keharusan. Oleh sebab itu meskipun tulisan ini menyajikan satu di antara kompetensi tersebut tidak berarti memisahkannya dari satua kesatuan dengan komptensi-kompetensi lainnya.

\section{B. Memahami Konsep Kompetensi Pedagogis}

Pedagogi secara etimologi berasal dari bahasa Yunani yaitu 'paid 'berarti "anak" dan 'agogus' berarti "membimbing. Oleh karena itu pedagogi sering diartikan sebagai ilmu dan seni untuk mengajarkan anak- 
anak (Depdiknas, 2006: 7). Direktorat Jenderal Pendidikan dan Tenaga Kependidikan (2006) menjabarkan kompotensi pedagogis kedalam subkompetensi dan indikator esensial sebagai berikut:

1. Memahami peserta didik. Subkompetensi ini memiliki indikator esensial; memahami peserta didik dengan memanfaatkan prinsipprinsip perkembangan kognitif; memahami peserta didik dengan memanfaatkan prinsip-prinsip kepribadian; dan mengidentifikasi bekal-ajar awal peserta didik.

2. Merancang pembelajaran, termasuk memahami landasan-landasan pendidikan untuk kepentingan pembelajaran. Subkompetensi ini memiliki indikator esensial; menerapkan teori belajar dan pembelajaran; menentukan strategi pembelajaran berdasarkan karakteristik peserta didik, kompetensi yang ingin dicapai, dan materi ajar; serta menyusuna rencana pembelajaran berdasarkan strategi yang dipilih.

3. Melaksanakan pembelajaran. Subkompetensi ini memiliki indikator esensial; menata latar (setting) pembelajaran; dan melaksanakan pembelajaran yang kondusif.

4. Merancang dan melaksanakan evaluasi pembelajaran. Subkompetensi ini memiliki indikator esensial: melaksanakan evaluasi (assessment) proses dan hasil belajar secara kesinambungan dengan berbagai metode; menganalisis hasil penilaian proses dan hasil belajar untuk menentukan tingkat ketuntasan belajar (mastery level); dan memanfaatkan hasil penilaian pembelajaran untuk perbaikan kualitas program pembelajaran secara umum.

5. Mengembangkan peserta didik untuk mengaktualisasikan berbagai potensi yang dimilikinya. Subkompetensi ini memiliki indikator esensial: memfasilitasi peserta didik untuk mengembangkan berbagai potensi akademik; dan memfasilitasi peserta didik untuk mengembangkan berbagai potensi nonakademik.

\section{Sub-sub Kompetensi Pedagogis}

\section{Pemahaman Peserta Didik}

Pemahaman peserta didik merupakan faktor yang sangat penting dalam pelaksanaan pendidikan dan pembelajaran. Jika guru memahami peserta didik dengan baik, maka ia dapat memilih dan menentukan sumber-sumber belajar yang tepat, pendekatan-pendekatan yang sesuai, mampu mengatasi masalah-masalah pembelajaran sehari-hari dengan baik, sehingga potensi anak dapat didorong untuk mencapai 
perkembangan yang optimal melalui penyelenggaraan proses pembelajaran.

Pemahaman potensi peserta didik merupakan kerangka dasar bagi pemahaman peserta didik secara keseluruhan. Kekeliruan pandangan terhadap eksistensi mereka seringkali menimbulkan dampak yang serius bagi anak. Sebagai contoh anak yang tinggal kelas sering dicap sebagai anak bodoh. Ini tentu anggapan serampangan sebab kenyataannya tidak selalu demikian. Seharusnya masalah-masalah ini dikaji dan dianalisis kasus per kasus. Dalam psikologi pendidikan dikatakan, anak-anak yang nunggak alias tinggal kelas umumnya tergolong sebagai anak yang underachiever atau tidak terpenuhi kebutuhannya (Suryana, 2007:1). Conny Semiawan, seorang pakar pendidikan, lebih jauh menjelaskan bahwa anak yang underachiever dalam kesehariannya kurang mendapat pengarahan sesuai dengan kebutuhannya. Misalnya saja, si anak senang sekali membaca tetapi di rumah tidak atau kurang disediakan sarana bacaan yang sesuai dengan usianya. Atau si anak gemar sekali musik, namun orang tua tidak memperbolehkannya ikut les musik karena takut mengganggu pelajaran sekolahnya.

Sebagai gambaran, Conny Semiawan mengibaratkan otak atau potensi seorang anak cerdas-berbakat bagaikan sebuah kendi besar. Kalau kendi itu tidak diisi penuh, si anak bisa membuat masalah. Anak yang berinteligensi jauh lebih tinggi dari rata-rata teman sekelasnya, akan merasa hampir setiap pelajaran membosankan karena daya tangkapnya juga lebih cepat dibandingkan dengan teman-temannya (Suryana, 2007:1). Seperti juga pernah dikatakan Yaumil Agus Achir, seorang pakar psikologi, dalam sebuah seminar dengan Intisari, banyak anak rendah prestasi belajarnya justru karena ia takut gagal. Soalnya, alam perasaannya diliputi kekecewaan, keragu-raguan, tekanan, dan anggapan bahwa dirinya kurang mampu. Ketidakberhasilan ini, menurut Yaumil, akibat terganggunya dorongan untuk meraih sukses sehingga anak lebih memusatkan perhatian pada usaha menyelamatkan diri dari kegagalan. Di sini motif menghindari kegagalan lebih besar daripada motif untuk berprestasi, sehingga si anak enggan mencoba mendapat nilai cemerlang. Sikap guru yang kejam dan galak, kurang berkomunikasi dengan murid, metode pengajaran yang kurang tepat dan terlalu cepat, materi pelajaran yang tidak ada kaitannya sama sekali dengan latar belakang kehidupan anak, ditambah lagi dengan permusuhan dengan teman, semua itu bisa menghambat prestasi anak.

Sebagaimana dikemukakan sebelumnya pemahaman peserta didik mencakup memahami peserta didik dengan memanfaatkan prinsip-prinsip 
perkembangan kognitif; memahami peserta didik dengan memanfaatkan prinsip-prinsip kepribadian, dan mengidentifikasi bekal-ajar awal peserta didik.

Berkenaan dengan prinsip-prinsip perkembangan kognitif, guru perlu memahami periode perkembangan kognitif anak. Pakar psikologi dari Swis, Jean Piaget mengemukakan empat periode perkembangan kognitif anak yaitu: periode sensorimotorik, periode operasi awal, periode operasi kongkrit dan periode operasi formal (Kartadinata dan Dantes 1996/1997: 60).

\section{(1) Periode sensorimotorik}

Menurut Piaget, sampai usia kurang lebih delapan belas bulan perkembangan skema lebih terpusat kepada sensorimotorik. Bayi mengembangkan dan mengkoordinasikan sejumlah besar ragam keterampilan perilaku, namun perkembangan skema verbal dan kognitif masih sangat miskin dan tidak terkoordinasikan. Pembentukan konsep pada periode ini terbatas pada objek permanen, yaitu objek yang tampak dalam batas pengamatan anak. Perilaku objektif secara perlahan-lahan berangsur bergerak ke arah kegiatan yang bertujuan.

(2). Periode operasi awal

Kurang lebih dari usia delapan belas bulan hingga kira-kira tujuh tahun, anak menginternalisasi skema sensorimotorik ke dalam bentuk skema kognitif (imajinasi dan pikiran). Seorang anak yang dihadapkan pada teka-teki, gambar atau menyusun balok, anak memulai kegiatannya dengan mengingat kembali pengalaman sebelumnya dalam situasi yang sama.

Skema yang berkembang pada masa ini belum merupakan skema yang stabil. Anak belum banyak belajar menimbang sesuatu berdasarkan persepsi orang lain. Oleh sebab itu kecakapan yang berkembang pada periode ini masih bersifat egosentrik. Artinya apa yang ia lakukan merupakan cara yang paling benar dan seolah-olah tidak ada alternatif lain. Di samping itu anak masih sangat mudah dibingungkan oleh keragaman objek. Kemampuan anak membedakan objek akan sangat tergantung pada ciri-ciri fisik permanen yang teramati.

(3). Periode operasi kongkrit

Sejak usia kurang lebih tujuh tahun samapi 12 tahun, perkembangan skema pada priode ini lebih berupa skema kognitif, terutama yang berkatan dengan keterampilan berpikir dan pemecahan 
masalah. Periode operasi kongkrit tidak hanya memungkinkan anak memecahkan masalah khusus, tetapi juga belajar untuk mempelajari keterampilan dan kecakapan berpikir logis yang membantu mereka memaknai pengalaman.

(4). Periode operasi formal

Periode ini berlangsung pada usia 12 tahun ke atas. Ciri utama dari periode operasi formal ini adalah perkembangan kecakapan berpikir simbolik dan pemahaman isi secara bermakna tanpa bergantung pada keberadaan objek fisik, atau bahkan pada imajinasi masa lalu akan objek sejenis. Anak yang berada pada periode operasi formal mampu berpikir logis dan matematis, abstrak dan bahkan mampu memahami hal-hal yang secara teoretik mungkin terjadi akan tetapi belum pernah terjadi dalam kenyataan.

Pemahaman peserta didik dengan memanfaatkan prinsip-prinsip kepribadian juga merupakan komponen penting dalam upaya mewujudkan efektivitas proses pendidikan dan pembelajaran. Asrori (2003: 6) mengemukakan bahwa perkembangan berbagai karakteristik individu tampak dalam aspek-aspek yang ada pada setiap diri individu yang meliputi perbedaan karakteristik individual; (a) aspek fisik, (b) aspek intelek, (c) aspek emosi, (d) aspek sosial, (e) aspek bahasa, (f) aspek bakat, $(\mathrm{g})$ aspek nilai, moral dan sikap.

Tiap-tiap aspek dia atas menunjukkan karakteristik individual yang berbeda sehingga tiap individu sebagai kesatuan jasmani dan rohani mewujudkan dirinya dirinya secara utuh dalam keunikannya. Dalam keadaan itu, maka harus dapat memahami keunikan-keunikan tersebut sehingga akan membantu memudahkan guru untuk memilih pendekatan yang sesuai dalam mendorong perkembangan peserta didik secara optimal.

\section{Merancang pembelajaran, termasuk memahami landasan- landasan pendidikan untuk kepentingan pembelajaran.}

Sebagaimana dikemukakan sebelumnya bahwa subkompetensi ini memiliki indikator esensial dalam bentuk aktivitas menerapkan teori belajar dan pembelajaran, menentukan strategi pembelajaran berdasarkan karakteristik peserta didik, kompetensi yang ingin dicapai, dan materi ajar, serta menyusun rencana pembelajaran berdasarkan strategi yang dipilih.

Tuntutan kemampuan guru yang semakin tinggi untuk mampu mengembangkan proses pembelajaran ini selaras dengan kebijakan pemerintah dalam bidang pendidikan terutama berkenaan dengan 
pengembangan kurikulum yang lebih menekankan pengembangan kompetensi peserta didik (competence-base curriculum). Pengelolaan Kurikulum menekankan berbagai pola pemberdayaan guru dan sumber daya lain untuk meningkatkan mutu hasil belajar dan penerapan strategi yang meningkatkan kebermaknaan pembelajaran untuk semua peserta didik terlepas dari latar budaya, etnik, agama dan jender (Balitbang Diknas, 2002: 2). Hal ini sudah barang tentu berimplikasi terhadap keharusan setiap guru untuk benar-benar memiliki pemahaman yang luas dalam bidang tugasnya sehingga dia dapat melakukan berbagai upaya inovatif untuk meningkatkan proses pembelajaran dan pendidikan secara keseluruhan.

Mencermati dinamika tuntutan tugas dan tanggung jawab guru sebagaimana dipaparkan di atas, maka Lembaga Pendidikan Tenaga Kependidikan yang memiliki tanggung jawab memproses dan menghasilkan calon-calon guru harus senantiasa mencari dan menemukan cara-cara yang lebih baik untuk dapat membekali peserta didik sebagai calon guru dengan perangkat pengetahuan dan nilai-nilai melalui perolehan pengalaman belajar yang memadai. Melalui pengetahuan dan pengalaman-pengalaman yang diperoleh oleh mahasiswa sebagai calon guru ini diharapkan mereka lebih memahami bidang tugasnya secara luas dan sekaligus memiliki bekal dasar yang memadai untuk selanjutnya dapat dikembangkan bersamaan dengan pelaksanaan tugas kelak sebagai guru. LPTK sebagai lembaga yang memiliki tanggung jawab mempersiapkan calon-calon guru, selayaknya mampu merancang dan mengimplementasikan proses pembelajaran yang memilliki karakteristik tersendiri bagi mahasiswa yang dipersiapkan untuk menjadi calon guru. Karakteristik utama yang harus dikembangkan selain tuntutan-tuntutan belajar pada umumnya adalah di mana mahasiswa sebagai calon guru harus lebih banyak dilibatkan atau mendapatkan kesempatan guna memperoleh pengalaman-pengalaman langsung di luar kelas yang berkaitan dengan bidang tugasnya. Pemberian kesempatan secara luas untuk mendapatkan pengalaman-pengalaman nyata berkaitan dengan tugasnya ini akan memberikan peluang bagi semakin kokohnya pemahaman mereka terhadap bidang bidang tugasnya, akan semakin tanggap dengan perubahan-perubahan yang terjadi serta mampu mengelaborasi pengetahuan-pengetahuan teoritik yang diperoleh dengan kehidupan nyata dalam ruang lingkup tugasnya. Dengan demikian mereka akan semakin siap menghadapi tugas-tugas profesioanal sebagai seorang guru kelak setelah menyelesaikan studi di lembaga pendidika tinggi. Tuntutan ini selaras dengan pandangan tentang kerangka kerja guru yang 
ideal yaitu seseorang yang mampu secara efisien menguasai dunia nyata (real world) dari sekolah. Pendidikan guru dalam hal ini bertujuan memberikan keterampilan dan pengalaman kepada peserta didik (Doyle, 1990: 5)

Merancang pembelajaran merupakan komponen kegiatan penting yang harus dilakukan guru. Dengan adanya rancangan kegiatan pembelajaran yang jelas, setidaknya memberikan manfaat dalam beberapa hal sebagai berikut:

a. Dapat mengarahkan proses belajar peserta didik

b. Dapat memilih materi, strategi instruksional, dan sumber belajar yang sesuai untuk dipakai dalam usaha membanu peserta didik dalam usaha belajarnya.

c. Dapat mengukur keberhasilan guru dalam pembelajarannya

d. Dapat mengukur sejauhmana peserta didik telah mencapai tujuan yang diinginkan

e. Dapat meningkatkan motivasi dengan mengetahui tingkat keberhasilan dalam proses belajar (Sumantri dan Permana, 1998/1999: 22).

Pada sisi lain pemahaman, wawasan atau landasan kependidikan merupakan keniscayaan bagi setiap guru agar mereka mampu memberikan arah bagi setiap aktivitas pendidikan dan pembelajaran yang dikelolanya. Sebagaimana diketahui bahwa tugas guru dalam pelaksanaan pembelajaran membutuhkan pemahaman dan wawasan yang mendalam tentang landasan kependidikan sehingga guru dapat mengantarkan peserta didik mencapai pengembangan potensi dirinya secara optimal sesuai dengan arah dan prinsip-prinsip pengembangan yang benar

Dalam pasal 1 Undang-undang Nomor 14 tahun 2005 tentang Guru dan Dosen diungkapkan bahwa kompetensi adalah seperangkat pengetahuan, keterampilan, dan perilaku yang harus dimiliki, dihayati, dan dikuasai oleh guru dalam melaksanakan tugas keprofesionalan. Pada pasal 10 Undang-undang Nomor 14 tahun 2005 selanjutnya disebutkan bawa Kompetensi guru meliputi: kompetensi pedagogik, kompetensi kepribadian, kompetensi sosial, dan kompetensi profesional yang diperoleh melalui pendidikan profesi. Meskipun terdapat pemisahan tersebut, tidak berarti bahwa kompetensi tersebut bersifat pragmenter, akan tetapi bersifat holistik karena antara satu kompetensi dengan kompetensi lainnya saling terkait pada performance guru.

Penguasaan landasan kependidikan meliputi; (a) memahami landasan kependidikan, (b) memahami kebijakan pendidikan, (c) 
memahami tingkat perkembangan siswa, (d) memahami pendekatan pembelajaran yang sesuai dengan materi pembelajarannya, (e) menerapkan kerjasama dalam pekerjaan, (f) memanfaatkan kemajuan IPTEK dalam pendidikan (Depdiknas, 2004: 9).

Pemahaman terhadap landasan pendidikan akan menjadi kerangka mendasar untuk menentukan langkah-langkah operasional dalam penyelenggaraan pendidikan dan pembelajaran sehingga dapat mengarah pada pencapaian tujuan pendidkan nasional yang diharapkan. Dalam Undang-Undang Sistem Pendidikan Nasional Nomor 20 tahun 2003 ditegaskan bahwa pendidikan nasional adalah pendidikan yang berdasarkan Pancasila dan Undang-Undang Dasar Negara Republik Indonesia Tahun 1945 yang berakar pada nilai-nilai agama, kebudayaan nasional Indonesia dan tanggap terhadap tuntutan perubahan zaman. Terkait dengan landasan tersebut, maka Visi pendidikan nasional adalah mewujudkan sistem pendidikan sebagai pranata sosial yang kuat dan berwibawa untuk memberdayakan semua warga negara Indonesia agar berkembang menjadi manusia yang berkualitas sehingga mampu dan proaktif menjawab tantangan zaman yang selalu berubah (Penjelasan PPRI Nomor 19 tahun 2005 tentang Standar Nasional Pendidikan).

\section{Melaksanakan pembelajaran}

Subkompetensi melaksanakan pembelajaran ini memiliki indikator esensial menata latar (setting) pembelajaran dan melaksanakan pembelajaran yang kondusif.

Untuk mendukung terwujudnya proses pembelajaran yang kondusif harus didukung oleh berbagai faktor, baik berkenaan dengan kemampuan guru, misalnya di dalam memilih bahan ajar, sarana dan fasiltas pendukung serta yang tidak kalah pentingnya kesiapan dan motivasi siswa untuk belajar dan mencapai hasil belajar yang optmal.

Dalam pemilihan bahan ajar, ada beberapa prinsip yang perlu diperhatikan. Prinsip-prinsip dalam pemilihan materi pembelajaran meliputi prinsip relevansi, konsistensi, dan kecukupan.

Prinsip relevansi artinya keterkaitan. Materi pembelajaran hendaknya relevan atau ada kaitan atau ada hubungannya dengan pencapaian standar kompetensi dan kompetensi dasar. Sebagai misal, jika kompetensi yang diharapkan dikuasai siswa berupa menghafal fakta, maka materi pembelajaran yang diajarkan harus berupa fakta atau gubahan hafalan. Prinsip konsistensi artinya keajegan. Jika kompetensi 
dasar yang harus dikuasai siswa empat macam, maka bahan ajar yang harus diajarkan juga harus meliputi empat macam. Misalnya kompetensi dasar yang harus dikuasai siswa adalah pengoperasian bilangan yang meliputi penambahan, pengurangan, perkalian, dan pembagian, maka materi yang diajarkan juga harus meliputi teknik penjumlahan, pengurangan, perkalian, dan pembagian. Prinsip kecukupan artinya materi yang diajarkan hendaknya cukup memadai dalam membantu siswa menguasai kompetensi dasar yang diajarkan. Materi tidak boleh terlalu sedikit, dan tidak boleh terlalu banyak. Jika terlalu sedikit akan kurang membantu mencapai standar kompetensi dan kompetensi dasar. Sebaliknya, jika terlalu banyak akan membuang-buang waktu dan tenaga yang tidak perlu untuk mempelajarinya.

Dalam proses belajar-mengajar, diharapkan tidak hanya berlangsung interaksi instruksional, tetapi juga interaksi pedagogis yang mengutamakan sentuhan-sentuhan emosional sehingga anak merasa senang belajar. Jean Piaget mengingatkan pentingnya metode mengajar anak yang seimbang dengan usia serta perkembangan fisik serta mental anak. Sebagai contoh Anak usia 7 - 10 tahun berada pada stadium operasional kongkret. Pada stadium ini anak sudah mampu melakukan aktivitas logis tertentu tetapi masih dalam situasi kongkret. Maksudnya, kalau anak dihadapkan pada suatu masalah secara verbal saja, tanpa bahan yang kongkret, ia akan sulit menuntaskan persoalannya secara baik. Bahan kongkret ini bisa berupa alat peraga. Mereka akan lebih mudah belajar menjumlahkan angka dengan menggunakan alat bantu sederhana seperti lidi atau batang korek api. Memberikan suatu pengertian bahwa sifat-sifat tertentu suatu objek akan tetap sama kendati ada transformasi pada objek tersebut (konservasi), bisa diperagakan misalnya dengan segenggam tanah liat yang diubah-ubah bentuknya menjadi segi tiga, segi empat, atau bulat. Bentuknya berubah tetapi beratnya tetap sama.

Metode pembelajaran yang baik harus didukung pula oleh berbagai faktor penunjang seperti perhatian serta dukungan orang tua, keadaan lingkungan serta kesehatan yang baik dan gizi anak yang cukup. Langkah-langkah yang perlu untuk menjalankan siasat jangka panjang demi perkembangan prestasi anak, menurut Yaumil Akhir, antara lain ialah lebih sering mengamati anak, mendengarkan obrolannya, mau berdialog dengannya, mendampinginya membuat PR. Langkah ini ditempuh agar orang tua mendapat masukan cukup yang diperlukan untuk 
menciptakan suasana belajar yang menyenangkan. Kalau sekali waktu anak gagal meraih prestasi, atau pahitnya sampai tidak naik kelas, hendaknya disikapi dengan empati, bukannya dihujani dengan serentetan makian atau hukuman yang merendahkan harga diri si anak. Untuk memperbaiki prestasinya, hendaknya ditelusuri penyebabnya. Kalau perlu, minta bantuan ahli atau guru kelasnya. Sebaliknya, berikan apresiasi (penghargaan misalnya pujian yang wajar, tidak selalu harus dalam bentuk materi) setiap kali anak menunjukkan prestasi. Anak butuh kasih sayang dan perhatian dari orang-orang yang terdekat dengannya, yaitu orang tua dan tentu juga guru.

\section{Merancang dan melaksanakan evaluasi pembelajaran}

Seperti diuraikan sebelumnya bahwa subkompetensi ini memiliki indikator esensial: melaksanakan evaluasi (assessment) proses dan hasil belajar secara kesinambungan dengan berbagai metode, menganalisis hasil penilaian proses dan hasil belajar untuk menentukan tingkat ketuntasan belajar (mastery level), dan memanfaatkan hasil penilaian pembelajaran untuk perbaikan kualitas program pembelajaran secara umum.

Evaluasi merupakan salah satu komponen sistem pendidikan/pembelajaran. Oleh sebab itu kemampuan guru melaksanakan evaluasi secara tepat akan memberikan pengaruh bagi peningkatan kualitas pembelajaran.

Untuk dapat melaksanakan evaluasi dengan benar, maka setiap guru dituntut memiliki perangkat pengetahuan tentang berbagai jenis evaluasi, prinsip-prinsip evaluasi, memilih jenis-jenis evaluasi sesuai dengan karakteristik dan tujuan pembelajaran serta prosedur implementasi dalam kegiatan pembelajaran. Dimyati dan Mujiono (1994:175), mengemukakan bahwa hal penting yang harus diketahui guru adalah bahwa secara umum evaluasi mencakup evaluasi hasil belajar dan evaluasi pembelajaran. Guru harus dapat membedakan antara kegiatan evaluasi hasil belajar dan evaluasi pebelajaran. Evaluasi hasil belajar menekankan kepada diperolehnya informasi tentang seberapakah perolehan siswa dalam mencapai tujuan pengajaran yang ditetapkan. Sedangkan evaluasi pembelajaran merupakan proses sistematis untuk memproleh informasi tentang keefektipan proses pembelajaran dalam membantu siswa mencapai tujuan pembelajaran secara optimal. Dengan demikian evaluasi belajar menyatakan baik buruknya hasil dari kegiatan pembelajaran, sedangkan evaluasi pembelajaran menyatakan baik buruknya proses dari kegiatan pembelajaran. 
Davies (1991:294) mengemukakan bahwa dengan melaksanakan evaluasi belajar dengan benar sekurang-kurangnya memungkinkan kita untuk; (1) mengukur kompetensi atau kapabilitas siswa, apakah mereka telah merealisasikan tujuan yang telah ditentukan, (2) menentukan tujuan mana yang belum direalisasikan, sehingga tindakan perbaikan yang cocok dapat direalisasikan, (3) merumuskan rangking siswa dalam hal kesuksesan mereka di dalam mencapai tujuan yang telah disepakati, (4) memberikan informasi kepada guru tentang cocok tidaknya strategi mengajar yang ia gunakan supaya kelebihan dan kekurangan strategi mengajar tersebut dapat ditentukan, (5) merencanakan prosedur untuk memperbaiki rencana pelajaran, dan menentukan apakah sumber belajar tambahan perlu digunakan.

Pelaksanaan evaluasi dalam pendidikan mempunyai manfaat yang luas, tidak sekedar mengukur keberhasilan proses belajar akan tetapi dapat memberikan manfaat dalam berbagai kegiatan lain baik bagi guru maupun bagi siswa (Nurkancana, 1986). Beberapa fungsi atau manfaat evaluasi pembelajaran tersebut adalah;

a. Untuk mengetahui taraf kesiapan anak untuk menempuh suatu pendidikan tertentu.

b. Untuk mengetahui seberapa jauh hasil yang telah dicapai dalam proses pembelajaran yang telah dilaksanakan.

c. Untuk mengetahui apakah suatu mata pelajaran yang kita ajarkan dapat kita lanjutkan dengan bahan yang baru ataukah kita harus mengulang pelajaran-pelajaran yang telah lampau.

d. Untuk mendapatkan bahan-bahan informasi apakah seorang anak dapat dinaikkan ke kelas yang lebih tinggi atau harus mengulang di kelas semula.

e. Untuk membandingkan apakah prestasi yang dicapai anak sudah sesuai dengan kapasitasnya atau belum.

f. Untuk mengadakan seleksi.

g. Untuk mengetahui taraf efisiensi metode yang dipergunakan.

Kemampuan memahami dan melaksanakan evaluasi ini menjadi tanggung jawab setiap guru. Di dalam proses pelaksanaannya guru sering menghadapi berbagai masalah yang mungkin tidak pernah ia ketehaui sebelumnya. Hal ini sangat mungkin terjadi karena dinamika proses pembelajaran dan peserta didik berlangsung secara dinamik sehingga sangat dimungkinkan munculnya berbagai fenoma-fenoma baru. Dalam keadaan ini setiap guru terus dituntut mengembangkan pengetahuannya, termasuk di dalam memahami dan menggunakan bentuk-bentuk evaluasi yang menggunakan alat-alat bantu teknologi. 


\section{Mengembangkan peserta didik untuk mengaktualisasikan berbagai potensi yang dimilikinya}

Subkompetensi ini memiliki indikator esensial: memfasilitasi peserta didik untuk mengembangkan berbagai potensi akademik, dan memfasilitasi peserta didik untuk mengembangkan berbagai potensi nonakademik.

Upaya-upaya pengembangan peserta didik agar mampu mengaktualisasikan potensi-potensi yang dimilikinya merupakan tangggung jawab seluruh guru. Dalam praktek pelaksanaan pendidikan di sekolah masih seringkali terdapat persepsi yang keliru yang memisahkan tanggung jawab guru dalam batas-batas pengembangan potensi tertentu dari peserta didik. Kita sering mendengar misalnya pihak yang menyatakan bahwa upaya pengembangan aspek-aspek nilai/moral hanya merupakan kewajiban guru-guru bidang studi tertentu saja, sehingga ada guru-guru yang mengasuh bidang studi yang lain merasa bahwa mereka hanya bertanggung jawab mengajarkan materi pelajaran yang menjadi muatan bidang studi yang diajarkannya. Padahal sesungguhnya pertumbuhan dan perkembangan murid merupakan tujuan yang ingin dicapai oleh semua sekolah dan guru, dan itu berarti sangat keliru jika guru hanya bertanggung jawab menyampaikan materi pelajaran pada bidang studinya saja (Gordon, 1997: 8) Guru memegang peranan strategis terutama dalam upaya membentuk watak bangsa melalui pengembangan kepribadian dan nilai-nilai yang diinginkan. Dari dimensi tersebut, peranan guru sulit digantikan oleh yang lain (Gaffar dalam Supriadi: 1998: xv). Karenanya dalam proses pembelajaran di kelas guru tidak cukup hanya berbekal pengetahuan berkenaan dengan bidang studi yang diajarkan, akan tetapi perlu memperhatikan aspek-aspek pendidikan lainnya yang memiliki kedudukan sama pentingnya untuk mendukung terwujudnya proses pembelajaran yang diharapkan. Mungkin benar apa yang dikatakan Ara Tai, anak usia 12 tahun asal Slandia Baru tentang guru yang baik. "Guru yang baik itu suka bekerja keras yang disertai kasih sayang. Tanpa didasari kasih sayang kepada kami anak-anak, semua yang dilakukan oleh guru itu sia-sia belaka," tulisnya seperti dikutip dalam buku terbitan UNESCO, What make a good teacher? (Supriadi, 1998: 12).

Kelas menjadi sentral dari upaya-upaya pengembangan potensipotensi peserta didik secara komprehensip. Karena itu proses pembelajaran di kelas harus benar-benar dirancang sebaik mungkin untuk memungkinkan berkembangnya potensi-potensi siswa secara optimal. Seluruh teori menempatkan secara sungguh-sungguh fungsi kelas dan 
kegiatan pembelajaran di dalam kelas sebagai dimensi pendidikan yang komprehensip. Oleh sebab itu kompetensi pedagogis, khususnya berkenaan dengan upaya mengaktualisasikan berbagai potensi yang dimiliki anak ini harus benar-benar mendapat perhatian yang serius dari semua guru.

\section{Penutup}

Perubahan-perubahan yang terjadi dalam kehidupan individu dan masyarakat semakin mendorong keharusan untuk memberikan layanan lebih profesional dalam berbagai bidang. Dalam keadaan ini pula, tuntutan kemampuan profesional guru dalam melaksanakan proses pendidikan/pembelajaran menjadi perhatian yang semakin serius oleh berbagai pihak.

Profesionalisme guru berakar dari kemampuan mengaktualisasikan empat kompetensi, yaitu kompetensi pedagogis, kompetensi kepribadian, kompetensi sosial dan kompetensi profesional. Keempat kompetensi ini merupakan kesatuan yang saling terkait. Kompetensi pedagogis yang dibahas dalam tulisan ini merupakan salah satu kompetensi yang menekankan pada kemampuan guru dalam pemahaman peserta didik terutama dalam rangka mendorong perkembangan kemampuan untuk untuk mengaktualisasikan berbagai potensi yang dimilikinya

dan melaksanakan proses pembelajaran dengan beberapa komponen kegiatannya. Dengan pemahaman yang mendalam tentang kompetensi ini diharapkan dapat mendorong guru untuk mencermati kembali kegiatankegiatan pembelajaran yang dilakukannya sehingga bersamaan dengan perjalan waktu dan upaya-upaya peningkatan kemampuan diri, maka profesionalisme guru yang diharapkan oleh semua pihak dapat terwujud.

\section{DAFTAR PUSTAKA}

Asrori, M. (2003). Perkembangan Peserta Didik. Malang: Wineka Media.

Davies, Ivor K. (1991), Pengelolaan Belajar. Jakarta: PAU Universitas Terbuka Bersama CV. Rajawali. 
Depdiknas. (2004). Standar Kompetensi Guru Sekolah Menengah Pertama. Jakarta: Direktorat Jenderal Pendidikan Dasar dan Menengah.

Depdiknas Direktorat Peningkatan Mutu Pendidik dan Tenaga Kependidikan. (2006). Bahan Sertifikasi Guru. Jakarta: Derektorat PMPTK.

Depdiknas, Direktorat Peningkatan Mutu Pendidik dan Tenaga Kependidikan Nonformal. (2006). Pengembangan Kompetensi Pedagogis dan Andragogi Tutor Pendidikan Kesetaraan. Jakarta: Direktorat PTK-PNF.

Dimyati dan Mudjiono. (1994). Belajar dan Pembelajaran. Jakarta: Proyek Pembinaan dan Peningkatan Mutu Tenaga Kependidikan Dirjen Dikti.

Doyle, Wr. (1990). "Thema in Teacher Education Research" dalam Handbook of Research on Teacher Education, A Project of the association of Teacher educator. New York: McMillan Publishing Comapny.

Gordon, T \& Burch, N. (1997). Menjadi Guru Efektif. Jakarta: PT. Gramedia Pustaka Utama.

Kartadinata, Sunaryo; Dantes Nyoman. (1996/1997). Landasan-Landasan Pendidikan Sekolah Dasar. Jakarta: Depdiknas Proyek Pengembangan Buku Sekolah Dasar.

Nurkancana, Wayan; Sumartana PPN. (1986). Evaluasi Pendidikan. Surabaya: Usaha Nasional.

Parkey, Forrest W. (1997). Becoming A Teacher. Fourth Edition. Boston/London: Allyn and Bacon.

Peraturan Pemerintah RI Nomor 19 tahun 2005 tentang Standar Nasional Pendidikan. Jakarta: Depdiknas. 
Supriad, Dedi. (1998). Mengangkat Citra dan Martabat Guru. Yogyakarta: Adicita Karya Nusa.

Suryana, Ahwan. (2007). Anak Bodoh Tapi Tinggal Kelas. Online.

Sumantri, Mulyani dan Permana, Johar. (1998/1999). Strategi Belajar Mengajar. Jakarta: Depdiknas Proyek Pengembangan Buku Sekolah Dasar.

Undang-Undang Republik Inonesia Nomor 20 Tahun 2003 tentang Sistem Pendidikan Nasional. Jakarta: Depdiknas.

Undang-Undang Republik Inonesia Nomor 14 tahun 2005 tentang Guru dan Dosen. Jakarta: Depdiknas. 